\title{
Edaphic natural selection of allozyme polymorphisms in Aegilops peregrina at a Galilee microsite in Israel
}

\author{
EVIATAR NEVO*, TAMAR KRUGMAN AND AVIGDOR BEILES \\ Institute of Evolution, University of Haifa, Mt. Carmel, Haifa 31905, Israel
}

\begin{abstract}
Allozymic diversity in proteins encoded by 19 loci was analysed electrophoretically in 70 individual plants of the wild tetraploid wheat Aegilops peregrina, from a microsite at Tabigha, north of the Sea of Galilee, Israel. The test involved a $100 \mathrm{~m}$ transect, equally subdivided into basalt and terra-rossa soil types and comparisons were based on the two polymorphic esterase loci. Significant genetic differentiation according to soil type was found over very short distances. Our results suggest that allozyme polymorphisms in $A$. peregrina are adaptive and that they differentiate primarily by soil selection, probably through aridity stress.
\end{abstract}

Keywords: Aegilops peregrina, genetic polymorphisms, microgeographic differentiation, natural selection.

\section{Introduction}

The debate whether allozyme polymorphisms are largely neutral (Kimura, 1983) or selected (Nevo, 1978, 1988; Nevo et al., 1984; Gillespie, 1991) is still quantitatively unresolved. Basically, this debate is an extension of a major unresolved problem in evolutionary biology concerning the relative importance of non-random and random processes in genetic structure, diversity and divergence in nature (Wright, 1931). Nevo (1988) summarized local, regional and global evidence in natural populations of plants and animals suggesting a major role for natural selection in orientation and maintenance of the levels and divergence of genetic polymorphisms (allozymes) and now also in differentiation of DNA polymorphisms (RFLPs) in relation to ecology and phylogeny (Nevo, 1991).

We have previously studied microgeographically the nature of allozymes and storage proteins in wild cereals at the Tabigha microsite, north of the Sea of Galilee (Nevo et al., 1981, 1983, 1988a) and other Israeli microsites (Nevo et al., 1986, 1988b, 1991; Golenberg \& Nevo, 1987). We have shown at the Tabigha microsite that soil type (basalt vs. terra-rossa) is an important

${ }^{*}$ Correspondence. selective force of qualitative and quantitative divergence of allozymes in wild barley, Hordeum spontaneum, and in wild emmer wheat, Triticum dicoccoides (Nevo et al., 1981, 1988a).

Here we tested a third cereal at the Tabigha microsite - a wild wheat, the tetraploid Aegilops peregrina. We show dramatic qualitative differentiation in one esterase locus and quantitative divergence in a second esterase locus according to soil type.

\section{Materials and methods}

Aegilops peregrina $(=A$. variabilis $=$ Triticum peregrinum) is an annual tetraploid (genomically US) wild wheat with wide morphological variation and extensive geographical range in the south and east Mediterranean (Kimber \& Feldman, 1987). All Aegilops species, except $A$. speltoides, are facultative selfers, i.e. are predominantly self-pollinated (Zohary, 1965).

$A$. peregrina is a common annual component of herbaceous open plant communities in primary and secondary habitats in east Mediterranean and IranoTuranian territories. Edaphically, it grows on many soil types in Israel and elsewhere (e.g. basalt, terra-rossa, rendzina, alluvial soils, marls, consolidated sand dunes, calcareous sandstones, red-sandy loams and loess). 


\section{Sampling and electrophoresis}

Our present sampling area was the Tabigha microsite north of the Sea of Galilee, at precisely the same transect (designated No. 1) where allozymic studies on wild barley and wild emmer wheat were previously conducted (see Nevo et al., 1981, 1988a for ecogeographical data). We assayed electrophoretically 70 individuals of Aegilops peregrina for diversity at 19 allozyme loci in a $100 \mathrm{~m}$ transect sampled on 8 June 1992. The transect was equally subdivided between the terrarossa soil on Middle Eocene hard limestones and brown basalt soils on Pleistocene basalt flows. Dispersal units (spikelets) were collected from 37 plants, about $1 \mathrm{~m}$ apart in the $50 \mathrm{~m}$ of terra-rossa subsection and from 33 plants from several clusters across the $50 \mathrm{~m}$ basalt subsection. Leaf and root tissues of laboratory germinated seedlings were homogenized and studied by starch gel electrophoresis. Sample preparation, enzyme assay methods and locus designation have been previously described (Brown et al., 1978; Nevo et al., 1991).

\section{Results}

The results and analysis are presented in Table 1. Of the 19 loci, 17 proved to be totally monomorphic on both soil types (Est-5, Ipor, Acph-1, Acph-2, Adh-1,

Table 1 Allele and haplotype frequencies of two polymorphic esterase loci and summary indices of genetic diversity based on 19 allozyme loci, in two soil subpopulations (each $50 \mathrm{~m}$ long) of Aegilops peregrina at Tabigha, Israel

\begin{tabular}{|c|c|c|c|c|c|c|}
\hline \multicolumn{2}{|c|}{ Soil type } & \multirow{3}{*}{$\begin{array}{l}\text { Terra-rossa } \\
37\end{array}$} & \multirow{3}{*}{$\begin{array}{l}\text { Basalt } \\
33\end{array}$} & \multirow[b]{3}{*}{ Mean } & \multirow[b]{3}{*}{ Total } & \multirow{3}{*}{$\begin{array}{l}\text { Significance } \\
P \text { by } \chi^{2}\end{array}$} \\
\hline \multicolumn{2}{|c|}{ Sample size } & & & & & \\
\hline Locus & Allele & & & & & \\
\hline \multicolumn{7}{|c|}{ a. Allele frequencies } \\
\hline \multirow[t]{2}{*}{ Est-1 } & $F$ & $0.028(2)$ & $1.00(66)$ & 0.493 & & \\
\hline & $S$ & $0.972(70)$ & $0.0(0)$ & 0.507 & & $<0.0005 \dagger$ \\
\hline \multirow[t]{2}{*}{ Est-2 } & $M$ & $0.514(38)$ & $0.750(48)$ & 0.623 & & \\
\hline & $N$ & $0.486(36)$ & $0.250(16)$ & 0.377 & & $0.045 \dagger$ \\
\hline \multicolumn{7}{|c|}{ b. Haplotype frequency } \\
\hline \multirow[t]{4}{*}{ Est-1,2 } & S-M & 17 & 0 & & 17 & \\
\hline & S-N & 18 & 0 & & 18 & \\
\hline & F-M & 1 & 24 & & 25 & \\
\hline & $\mathrm{F}-\mathrm{N}$ & 0 & 8 & & 8 & $<0.0005$ \\
\hline Total & & 36 & 32 & & $68 \ddagger$ & \\
\hline
\end{tabular}

\begin{tabular}{|c|c|c|c|c|c|}
\hline \multirow[b]{2}{*}{ Soil type } & \multirow{2}{*}{$\begin{array}{l}\text { Sample } \\
\text { size } \\
(\mathrm{N})\end{array}$} & \multirow{2}{*}{$\begin{array}{l}\text { Mean no. of } \\
\text { alleles per } \\
\text { locus (A) }\end{array}$} & \multicolumn{2}{|c|}{$\begin{array}{l}\text { Mean proportion } \\
\text { of polymorphic } \\
\text { loci per popula- } \\
\text { tion }(\mathbf{P})\end{array}$} & \multirow{2}{*}{$\begin{array}{l}\text { Genic } \\
\text { diversity } \\
\left(\mathbf{H}_{c}\right)\end{array}$} \\
\hline & & & $(1 \%)$ & $(5 \%)$ & \\
\hline \multicolumn{6}{|c|}{ c. Genetic summary } \\
\hline Terra-rossa & 37 & 1.105 & 0.105 & 0.053 & 0.029 \\
\hline Basalt & 33 & 1.053 & 0.053 & 0.053 & 0.020 \\
\hline Mean & & 1.079 & 0.079 & 0.053 & 0.024 \\
\hline Sum & 70 & & & & \\
\hline
\end{tabular}

Number of alleles appear in parentheses.

$\dagger$ Because of inbreeding, the significance has been calculated from genotype frequencies.

$\ddagger$ One plant was not scored for $E s t-1$ and another one not for $E s t-2$. Therefore, only in 68 plants could the haplotype be determined. 
Gdh, Got-1, Got-2, G6pdh, Nadh-1, Pepc, Pept-1, Pept2, 6Pgd-2, Pgi-A, Pgi-B, Pgm; for full names of loci see Nevo et al. (1991). The remaining two loci, esterases Est -1 and Est-2, were highly polymorphic and Est-1 was nearly alternatively fixed in the two soils (Table 1a). Thus, Est-1 shows qualitative allele and genotype fixation: $S$ was found only in terra-rossa plants and $F$ almost so in basalt plants. No heterozygotes were found at this locus. By contrast, the Est-2 divergence in plants according to soil was quantitative: $\mathrm{M}$ prevailed on the basalt and $\mathrm{N}$ frequency was significantly higher on the terra-rossa $\left(\chi^{2}=4.09, P=0.045\right)$. Two heterozygotes, $\mathrm{MN}$, were found on terra rosa.

A haplotype analysis appears in Table 1b. Divergence between haplotypes is dramatic: while the SM and $\mathrm{SN}$ haplotypes grew only on the terra-rossa, the FN haplotype was found only on basalt and FM almost so.

The Nei (1972) genetic distance between the two subpopulations of $A$. peregrina was $\mathrm{D}=0.056 \pm 0.003$. The $G_{s t}(\mathrm{Nei}, 1973)$ analysis of the two soil subpopulations indicates high divergence between them, primarily due to Est-1 with $G_{\text {st }}=0.944$, resulting in a total $G_{\mathrm{st}}=0.515$. In other words, 94 per cent of the gene diversity of Est-1 diverged between the two soil subpopulations and more than half the total diversity exists between the two subpopulations.

\section{Discussion}

The genetic divergence presented here for Aegilops peregrina at Tabigha is associated with soil differences. It corroborates earlier studies along the same transect, equally subdivided by the two soils, in diploid wild barley Hordeum spontaneum (Nevo et al., 1981, 1983), and in tetraploid wild emmer wheat (Nevo et al., 1988a). However, the level of genetic polymorphisms in A. peregrina is much lower than in the other two wild cereals (Table 1c), although genetic differentiation is stronger. These studies, as other microsite studies (Nevo et al., 1986, 1988b, 1991), strongly suggest edaphic and/or climatic natural selection as a differentiating factor either directly on the esterase loci or on an associated block of genes (Hedrick, 1982).

The pattern obtained is unlikely to result from neighbourhood size or from any random/neutral explanatory model (e.g. Kimura, 1983). The populations are large, hence the pattern cannot derive from small size population effects. Likewise, due to the short distances involved of tens of metres, gene flow must occur in both directions and could easily equalize the allele frequencies at the two polymorphic esterase loci on both soil types, unless counteracted by diversifying soil selection. It is noteworthy that selection may operate on multilocus structures (e.g. Golenberg \& Nevo, 1987) comprising the two esterase loci and/or associated genes, rather than on each separately as shown in Table 1b.

Microgeographic genetic divergence, despite gene flow, following ecological heterogeneity has been shown in Avena (Allard et al., 1972; Hamrick \& Allard, 1972) and other plants (reviewed in Bradshaw, 1972; Brown, 1979), as well as in the Triticeae, $H$. spontaneum and $T$. dicoccoides, in the same transect at Tabigha and elsewhere (overviewed in Nevo, 1988 and studied spatiotemporally by Nevo et al., 1991). Such genetic divergence can take place over very short distances and seems to be adaptive at the level of allozyme polymorphism. It suggests the operation of edaphic diversifying natural selection, in accordance with the ecological niche model of Levene (1953), and the migration-selection model of Karlin (1982). It remains, however, to identify the specific selective soil component(s) and the precise target of selection.

It is likely that soil selection may operate through aridity stress as soil water contents and drought dynamics vary drastically between terra-rossa and basalt, leading to earlier ripening of herbaceous plants on the terra-rossa (Nevo et al., 1988a; Rabinovitch-Vin \& Orshan, 1974). Aridity stress was also suggested as a major evolutionary divergence force in $T$. dicoccoides at the Ammiad microsite where soil was uniform but topography and lithology may have lead to diversifying aridity stress in space and time (Nevo et al., 1991). Reciprocal transplant experiments of genotypes from both soil types could assess their fitness components directly (B. Lavie et al., unpublished data). It also remains to unravel the biochemical kinetics, physiological differences and evolutionary dynamics of the esterase alleles or haplotypes and their contribution to fitness on the two soil types.

\section{Acknowledgements}

We are grateful to T. Kawahara, T. Yamada and D. Zohary for field assistance in collecting the seeds. We thank the Israeli Discount Bank Chair of Evolutionary Biology and the Ancell-Teicher Research Foundation for Genetics and Molecular Evolution established by Florence and Theodore Baumritter of New York for financial support of this research.

\section{References}

ALlARD, D. R. W., BABBEL, G. R., CLEGG, M. T. AND KAHLER, A. L. 1972. Evidence for coadaptation in Avena barbata. Proc. Nat. Acad. Sci. USA, 69, 3043-3048. 
BRADSHAW, A. D. 1972. Some of the evolutionary consequences of being a plant. Evol. Biol., 5, 25-47.

BRoWN, A. H. D. 1979. Enzyme polymorphism in plant populations. Theor. Pop. Biol., 15, 1-42.

BRown, A. H. D., NEVo, E,. ZOHARY, D. AND DAGAN, O. 1978. Genetic variation in natural populations of wild barley (Hordeum spontaneum). Genetica, 49, 97-108.

GILlesPIE, J. 1991. The Causes of Molecular Evolution. Oxford University Press, New York, Oxford.

GOLENBERG, E. M. AND NEVO, E. 1987. Multilocus differentiation and population structure in a selfer, wild emmer wheat, Triticum dicoccoides. Heredity, 58, 451-456.

HAMRICK, J. L. AND ALLARD, R. W. 1972. Microgeographical variation in allozyme frequencies in Avena barbata. Proc. Nat. Acad. Sci. USA, 69, 2100-2104.

HEDRICK, P. W. 1982. Genetic hitchhiking: a new factor in evolution. Bioscience, 32, 845-853.

KARLIN, s. 1982. Classifications of selection-migration structures and conditions for a protected polymorphism. Evol. Biol., 14, 61-204.

KIMBER, G. AND FELDMAN, M. 1987. Wild Wheat. Special Report 353, College of Agriculture, University of Missouri, Columbia, p. 64.

KImURA, M. 1983. The Neutral Theory of Molecular Evolution. Cambridge University Press, London.

LEVENE, H. 1953. Genetic equilibrium when more than one ecological niche is available. Am. Nat., 87, 331-333.

NEI, M. 1972. Genetic distance between populations. Am. Nat., 106, 283-292.

NEI, M. 1973. Analysis of gene diversity in subdivided populations. Proc. Nat. Acad. Sci. USA, 70, 3321-3323.

NEVO, E. 1978. Genetic variation in natural populations: patterns and theory. Theor. Pop. Biol., 13, 121-177.

NEVO, E. 1988. Genetic diversity in nature: patterns and theory. Evol. Biol., 23, 217-246.

NEVO, E. 1991. Evolutionary theory and processes of active speciation and adaptive radiation in subterranean mole rats. Spalax ehrenbergi superspecies in Israel. Evol. Biol., 25, 1-125.
NEVO, E., BEILES, A. AND BEN-SHLOMO, R. 1984. The evolutionary significance of genetic diversity: ecological, demographic and life history correlates. Lect. Notes in Biomath., 53, $13-213$.

NEVO, E., BEILES, A. AND KRUGMAN, T. 1988a. Natural selection of allozyme polymorphisms: a microgeographical differentiation by edaphic, topographical and temporal factors in wild emmer wheat (Triticum dicoccoides). Theor. Appl. Genet., 76, 737-752.

NEVO, E., BEILES, A. AND KRUGMAN, T. 1988b. Natural selection of allozyme polymorphisms: a microgeographic climatic differentiation in wild emmer wheat (Triticum dicoccoides). Theor. Appl. Genet., 75, 529-538.

NEVO, E., BEILES, A., STORCH, N., DOLL H. AND ANDERSON, B. 1983. Microgeographic edaphic differentiation in hordein polymorphisms of wild barley. Theor, Appl. Genet. 64, 123-132.

NEVO, E., BROWN, A. H. D., ZOHARY, D., STORCH, N. AND BEILES, A. 1981. Microgeographic edaphic differentiation of allozyme polymorphisms of wild barley. Plant Syst. Evol., 138, 287-292.

NEVO, E., NOY-MEIR, I., BEILES, A., KRUGMAN, T. AND AGAMl, M. 1991. Natural selection of allozyme polymorphisms: microgeographical spatial and temporal ecological differentiations in wild emmer wheat. Isr. J. Bot., 40, 419-449.

NEVO, E., BEILES, A., KAPLAN, D., GOLENBERG, E. M., OLSVIGWHITTAKER, L. AND NAVEH, Z. 1986. Natural selection of allozyme polymorphisms: a microsite test revealing ecological genetic differentiation in wild barley. Evolution, 40, $13-20$

RABINOVITCH-VIN, A. AND ORSHAN, G. 1974. Ecological studies on the vegetation of the Upper Galilee, Israel. II. Factors determining the absence of batha and garigue components on Middle Eocenian strata. Isr. J. Bot., 23, 111-119.

WRIGHT, s. 1931. Evolution in Mendelian populations. Genetics, 16, 97-159.

ZOHARY, D. 1965. Colonizer species in the wheat group. In: Baker, H. G. and Stebbins, G. L. (eds) The Genetics of Colonizing Species, pp. 403-423. Academic Press, New York. 